\title{
STATUS MIKROBIOLOGI (Total Plate Count dan Staphylococcus aureus) SUSU SAPI PERAH DI KABUPATEN TANGGAMUS PROVINSI LAMPUNG
}

\author{
Microbiology Status (Total Plate Count and Staphylococcus aureus) of Milk of Dairy Cows in \\ Tanggamus Regency, Lampung Province
}

\author{
Oktora Luhur Handika, Veronica Wanniatie, Purnama Edy Santosa, Arif Qisthon \\ Departement of Animal Husbandry, Faculty of Agriculture, University of Lampung \\ Jl. Prof. Dr. Soemantri Brojonegoro No.1 Gedong Meneng Bandar Lampung 35145 \\ e-mail : oktorahandika@gmail.com
}

\begin{abstract}
This study aimed to determine the microbiological status (Total Plate Count and Staphylococcus aureus) of milk of dairy cows of people's farms. Research location was in Tanggamus Regency, Lampung Province. This research used survey method with census methods. Fresh milk samples were taken during milking in the morning, which is as much as $250 \mathrm{ml}$ from all lactating cows. In addition, this study also used questionnaire to know the condition of the dairy cows. Nineteen milk samples were analyzed at the Veterinary Public Health Laboratory of Lampung Veterinary Center, Bandar Lampung. Analysis of milk microbiological status was based on Total Plate Count and Staphylococcus aureus. The results of this study indicated that $100 \%$ of milk samples had Total Plate Count and Staphylococcus aureus values below the maximum SNI number of 3141.1: 2011. Milk of dairy cow in Tanggamus Regency, Lampung Province is feasible and safe for consumption.
\end{abstract}

Keywords: Dairy cows, Microbiological status, Milk.

\begin{abstract}
ABSTRAK
Penelitian ini bertujuan untuk mengetahui status mikrobiologi (Total Plate Count dan Staphylococcus aureus) susu sapi perah di peternakan rakyat. Lokasi penelitian di Kabupaten Tanggamus Provinsi Lampung. Penelitian ini menggunakan metode survei dan sensus. Sampel susu segar diambil saat pemerahan di pagi hari sebanyak $250 \mathrm{ml}$ dari semua sapi laktasi, selain itu juga diberikan kuisioner. Sampel susu sebanyak 19 sampel dianalisis di Laboratorium Kesmavet Balai Veteriner Lampung, Bandar Lampung. Analisis status mikrobiologi susu dilakukan terhadap nilai Total Plate Count dan Staphylococcus aureus. Hasil penelitian ini menunjukkan bahwa 100\% sampel susu memiliki nilai Total Plate Count dan Staphylococcus aureus di bawah batas maksimum SNI nomor 3141.1:2011. Susu sapi perah yang diproduksi di Kabupaten Tanggamus Provinsi Lampung layak dan aman untuk dikonsumsi.
\end{abstract}

Kata Kunci: Sapi perah, Status mikrobiologi, Susu.

\section{PENDAHULUAN}

Indonesia merupakan negara berkembang dengan jumlah penduduk 269 juta jiwa dan akan terus bertambah setiap tahunnya (Jayani, 2019). Peningkatan jumlah penduduk akan diiringi dengan meningkatnya kebutuhan protein hewani, salah satunya bisa berasal dari susu sapi. Susu sapi dihasilkan dari sekresi kelenjar susu yang sedang dalam masa laktasi dan dalam keadaan sehat (BSN, 2011). Susu mengandung zat-zat makanan yang lengkap seperti lemak, protein, mineral, vitamin, dan laktosa yang sangat dibutuhkan oleh tubuh manusia.

Susu yang banyak dikonsumsi secara luas di Indonesia berasal dari susu sapi Friesian Holstein (FH) dan Peranakan Friesian Holstein
(PFH). Sapi FH berasal dari Belanda yaitu di Provinsi North Holand dan West Friesland. Sapi PFH merupakan hasil persilangan antara sapi FH dengan sapi setempat atau sapi lokal yang ada di Indonesia dan tersebar di pulau Jawa.

Tahun 2018 populasi sapi perah di Provinsi Lampung sebanyak 444 ekor (Dirjen Peternakan dan Kesehatan Hewan, 2018), yang tersebar di empat kabupaten, diantaranya Tanggamus, Lampung Tengah, Lampung Barat dan Pesawaran. Kabupaten Tanggamus merupakan salah satu wilayah di Provinsi Lampung yang memiliki karakteristik hampir $50 \%$ berbukit dan bergunung, sedangkan wilayah datarnya hanya sekitar $19 \%$ dari keseluruhan wilayah. Sebagian besar dari wilayah Kabupaten Tanggamus dipengaruhi oleh udara tropikal 
pantai dan dataran dengan temperatur udara ratarata $28^{\circ} \mathrm{C}$ (Pemkab Tanggamus, 2019).

Susu sapi segar termasuk pangan asal hewan yang bersifat mudah rusak karena mengandung zat gizi yang baik untuk pertumbuhan mikroba. Mikroba patogen seperti Salmonella, Campylobacter, Staphylococcus aureus, Basillus cereus, Clostridium botulinum dan Escherichia coli yang dapat menyebabkan keracunan makanan bila mengkontaminasi susu (Darmansah, 2011). Kontaminasi mikroba tersebut dapat diakibatkan kurangnya menjaga kebersihan saat proses pemerahan, adanya kontak langsung dengan debu, peralatan pemerahan yang tidak dijaga kebersihannya, dan tangan pemerah yang kotor (Syarif et al., 2011). Perlu dilakukan prosedur pemerahan yang baik untuk mencegah terjadinya kontaminasi mikroba pada susu, meliputi persiapan sapi yang akan diperah, kondisi kandang, kondisi pemerah, peralatan, dan tempat penyimpanan (Santoso et al., 2012).

Prosedur pemerahan yang ada di peternakan sapi perah di Kabupaten Tanggamus diterapkan dengan cukup baik, namun belum diketahui status mikrobiologinya sebagai indikator keamanan pangan. Pemeriksaan status mikrobiologi pada susu sapi dilakukan agar konsumen terhindar dari keracunan susu. Oleh sebab itu, perlu dilakukannya penelitian untuk mengetahui status mikroba (Total Plate Count /TPC dan $S$. aureus) susu sapi perah di peternakan rakyat Kabupaten Tanggamus Provinsi Lampung.

\section{MATERI DAN METODE}

Penelitian ini dilaksanakan pada Januari 2020 dengan pengambilan sampel susu dan kuesioner di peternakan sapi perah di Kecamatan Gisting dan Kecamatan Air Naningan, Kabupaten Tanggamus. Status mikrobiologi susu (Total Plate Count dan S. aureus) dianalisis di Balai Veteriner Lampung, Bandar Lampung.

\section{Bahan dan Alat}

Alat yang digunakan dalam penelitian ini yaitu botol steril, colling box, cawan petri, tabung reaksi, tabung durham, pipet volumetrik, botol media, penghitung koloni (colony counter), gunting, pinset, jarum inokulasi (ose), stomacher, pembakar bunsen, batang gelas bengkok (hockey stick), timbangan, magnetic stirer, pengocok tabung (vortex), inkubator, penangas air, lemari steril (clean bench), freezer dan refrigerator. Bahan yang digunakan dalam pengujian status mirobiologi susu sapi yaitu susu sapi segar, es batu, akuades, Buffer Peptone
Water (BPW) 0,1\%, Plate Count Agar (PCA), egg yolk tellurite emultion, Baird Parked Agar (BPA), Tryptone Soy Agar (TSA), dan koagulase plasma kelinci (coagulate rabbit plasma) dengan EDTA 0,1\%.

\section{Metode}

Penelitian ini dilakukan dengan menggunakan metode survei. Sampel susu diambil dengan cara sensus pada sapi yang sedang laktasi, susu segar diambil saat pemerahan di pagi hari sebanyak $250 \mathrm{ml}$ dari masing-masing sapi laktasi (Hijriah et al., 2016) dan memberikan kuisioner kepada peternak. Prosedur awal yang digunakan untuk mengambil sampel antara lain melakukan wawancara kepada semua peternak sapi perah dengan kuisioner; menyiapkan cooling box dan es batu; mengambil sampel susu pada pagi hari sebanyak $250 \mathrm{ml}$ dari masing-masing sapi laktasi dan dimasukkan ke dalam botol steril; memasukkan sampel susu yang telah dikoleksi ke dalam cooling box dan dijaga agar kondisi susu tetap dingin; serta membawa sampel susu ke Laboratorium Kesmavet di Balai Veteriner Lampung untuk dilakukan pemeriksaan terhadap TPC dan S. aureus.

\section{Peubah yang Diukur}

Peubah yang diukur pada penelitian ini adalah jumlah TPC dan $S$. aureus yang diuji sesuai dengan prosedur Balai Veteriner Lampung.

\section{Analisis Data}

Data Total Plate Count (TPC) dan S. aureus yang diperoleh dibuat dalam bentuk tabulasi sederhana dan dianalisis secara deskriptif serta dibandingkan dengan SNI 3141.1:2011 tentang syarat susu segar.

\section{HASIL DAN PEMBAHASAN}

\section{Total Plate Count (TPC)}

Hasil pengujian TPC susu sapi perah di Kabupaten Tanggamus Provinsi Lampung dapat dilihat pada Tabel 1. Tabel 1 menunjukkan bahwa seluruh sampel susu sapi perah yang diambil di Kabupaten Tanggamus Provinsi Lampung mengandung jumlah bakteri di bawah batas maksimum cemaran mikroba yang telah ditentukan atau telah memenuhi syarat dari SNI 3141.1:2011 tentang syarat susu segar, yaitu sebesar $1 \times 10^{6} \mathrm{cfu} / \mathrm{ml}$. Total Plate Count (TPC) adalah suatu metode uji untuk menilai manajemen dan kualitas susu dengan memperkirakan jumlah kontaminasi mikroba 
total yang ada pada susu. Total Plate Count (TPC) memberikan gambaran kualitas dan higiene susu secara keseluruhan (Elmoslemany et al., 2010; Wanniatie et al., 2019).

Tabel 1. Jumlah Total Plate Count (TPC) pada susu sapi perah di Kabupaten Tanggamus

\begin{tabular}{ccc} 
No & Kode Sampel & Total Plate Count $(\mathrm{CFU} / \mathrm{ml})$ \\
\hline 1 & G1 & $1,0 \times 10^{2 *}$ \\
2 & G2 & $1,0 \times 10^{2 *}$ \\
3 & G3 & $9,0 \times 10^{3 *}$ \\
4 & G4 & $9,0 \times 10^{3 *}$ \\
5 & G5 & $1,0 \times 10^{2 *}$ \\
6 & G6 & $1,1 \times 10^{4 *}$ \\
7 & G7 & $1,0 \times 10^{2 *}$ \\
8 & G8 & $9,0 \times 10^{3 *}$ \\
9 & G9 & $1,0 \times 10^{2 *}$ \\
\hline & A1 & $4,28 \times 10^{3}$ \\
\hline 10 & A2 & $1,4 \times 10^{3 *}$ \\
11 & A3 & $1,5 \times 10^{3 *}$ \\
12 & A4 & $1,0 \times 10^{4 *}$ \\
13 & A5 & $3,1 \times 10^{3 *}$ \\
14 & A6 & $2,8 \times 10^{3 *}$ \\
15 & A7 & $1,3 \times 10^{4 *}$ \\
16 & A8 & $2,9 \times 10^{3 *}$ \\
17 & A9 & $3,1 \times 10^{3 *}$ \\
18 & A10 & $3,0 \times 10^{2 *}$ \\
19 & Rata-rata & $1,2 \times 10^{3 *}$ \\
\hline
\end{tabular}

Keterangan :

G: Gisting

A: Air Naningan

$(*)$ : Sesuai SNI $\left(<1 \times 10^{6} \mathrm{cfu} / \mathrm{ml}\right)$

$(* *)$ : Tidak Sesuai SNI $\left(>1 \times 10^{6} \mathrm{cfu} / \mathrm{ml}\right)$

Secara umum rata-rata nilai TPC susu sapi perah di Kecamatan Gisting lebih tinggi dibandingkan dengan susu sapi perah di Kecamatan Air Naningan. Sampel susu sapi perah di Kecamatan Air Naningan yang mengandung jumlah bakteri tinggi atau memiliki nilai TPC tertinggi yaitu pada sampel susu sapi

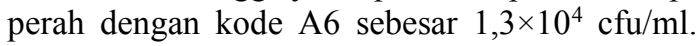
Sedangkan sampel susu sapi perah di Kecamatan Gisting yang mengandung jumlah bakteri tinggi atau memiliki nilai TPC tertinggi yaitu pada sampel susu sapi perah dengan kode G6 sebesar $1,1 \times 10^{4} \mathrm{cfu} / \mathrm{ml}$. Menurut Syamsi et al. (2018), sumber kontaminasi susu berasal dari berbagai faktor yang meliputi peternak itu sendiri, peralatan pemerahan, proses pemerahan, dan lain sebagainya.

Jarak kandang sapi perah dengan pembuangan limbah yang ada di Kecamatan Air Naningan berjarak 3 meter serta limbah diolah dengan baik. Sedangkan tata letak kandang sapi perah di Kecamatan Gisting berdekatan dengan pembuangan limbah yaitu dengan jarak 2 meter, selain itu limbah peternakan yang dihasilkan tidak diolah dengan maksimal. Limbah yang ada hanya dibuang di sekitar kandang dan tidak dilakukan pengolahan sehingga dapat mempengaruhi kualitas susu yang dihasilkan. Polutan tidak kasat mata seperti mikroba yang mengkontaminasi udara dapat menjadi sumber pencemaran (Berliana, 2016). Menurut Permatasari (2018), terjadinya kontak langsung dengan limbah ternak dapat mempengaruhi higiene peternak dan kualitas susu yang dihasilkan.

Kebersihan kandang menjadi salah satu hal penting untuk meminimalisir cemaran mikroba pada susu dan dapat mencegah terjangkitnya penyakit pada sapi. Proses pembersihan kandang sapi perah yang ada di Kecamatan Gisting dan Air Naningan dilakukan sekali pada pagi hari saja, sehingga akan menyebabkan penumpukan kotoran pada sore hari. Menurut Permatasari (2018), dalam sehari seekor sapi akan menghabiskan $60 \%$ waktunya untuk beristirahat dan berbaring di dalam kandang. Kotoran yang tidak dibersihkan akan menempel pada ambing bahkan pada seluruh 
tubuh sapi, sehingga dapat menjadi salah satu penyebab kontaminasi mikroba pada susu yang diproduksi. Hal tersebut sesuai dengan pendapat Santoso et al. (2010) yang menyatakan bahwa kebersihan tubuh sapi dan kandang akan mempengaruhi jumlah mikroba pada susu yang dihasilkan.

Sebelum dilakukannya pemerahan, peternakan sapi perah di Kecamatan Gisting dan Air Naningan, keduanya memandikan sapi dan membersihkan lantai menggunakan air sumur. Tinggi rendahnya nilai TPC dalam susu dapat diakibatkan adanya pencemaran air sumur yang tidak bersumber pada titik tertentu, misalkan polusi yang berasal dari limbah rumah tangga, kotoran manusia atau hewan, dan limbah industri (Wiryono, 2013). Kedua peternakan tersebut tidak melakukan dipping puting menggunakan antiseptik setelah pemerahan, namun keduanya sama-sama melakukan pengelapan dengan air hangat pada ambing. Menurut Elmoslemany et al. (2010), pengelapan menggunakan air hangat pada ambing akan meminimalisir total mikroba pada susu. Menurut Syamsi et al. (2018), mengelap ambing dengan air hangat akan menstimulus sapi untuk mensekresi hormon oksitosin yang berguna agar susu mudah keluar dari ambing saat dilakukannya pemerahan. Proses pemerahan yang dilakukan pada kedua peternakan tersebut sudah menggunakan mesin pemerah. Menurut Azwar (1996), penggunaan mesin pemerah dapat meminimalisir terjadinya kontak langsung antara tangan dengan susu, sehingga dapat meminimalisir pencemaran mikroba dari tangan ke susu.

Peralatan yang akan digunakan pada peternakan sapi perah di Kecamatan Gisting dan Air Naningan telah dilakukan penyucian menggunakan air dan sabun. Setelah digunakan peralatan kemudian dicuci kembali menggunakan air dan sabun. Menurut Frank (2001), sabun adalah salah satu golongan surfaktan (surface active agents) yang dapat membunuh mikroba dengan cara merusak membran sel. Menurut Rombaut (2005), pencemaran mikroba pada susu dapat berasal dari peralatan pemerahan yang tidak dicuci sebelum dan sesudah digunakan.

Sampel susu sapi perah di Kabupaten Tanggamus Provinsi Lampung (Tabel 1) memiliki nilai TPC yang memenuhi syarat SNI 3141.1:2011. Hal ini berarti bahwa susu yang dihasilkan aman dan layak untuk dikonsumsi oleh masyarakat. Susu sapi yang akan dikonsumsi sebaiknya terlebih dahulu dipanaskan atau diolah dengan cara pasteurisasi.

\section{Staphylococcus aureus}

Tabel 2 menunjukkan rata-rata jumlah cemaran $S$. aureus dalam susu sapi perah di Kabupaten Tanggamus Provinsi Lampung telah memenuhi syarat SNI, yaitu di bawah batas maksimum cemaran $S$. aureus sebesar $1 \times 10^{2}$ $\mathrm{cfu} / \mathrm{ml}$ (BSN, 2011). Jumlah $S$. aureus di Kecamatan Gisting lebih tinggi dibandingkan dengan Kecamatan Air Naningan yaitu sebesar $1,5 \times 10^{1} \quad \mathrm{cfu} / \mathrm{ml}$. Sedangkan sampel susu terbanyak yang tidak terdapat bakteri $S$. aureus yaitu pada peternakan sapi perah di Kecamatan Air Naningan. Perbedaan hasil dapat diakibatkan adanya perbedaan kebersihan kandang, kebersihan peralatan, dan proses pemerahan dari kedua peternakan tersebut. Kontaminasi mikroba pada susu dapat terjadi secara langsung melalui ambing, pemerah, alat-alat pemerahan, air, udara, dan tempat penyimpanan susu (Lund et al., 2000).

Kebersihan kandang menjadi salah satu hal yang sangat penting untuk meminimalisir terkontaminasinya $S$. aureus pada susu yang dihasilkan. Menurut Cahyono (2013), cemaran S. aureus dapat berasal dari hewan lain, manusia, dan udara. Lantai yang telah terkontaminasi bakteri $S$. aureus dan dalam keadaan kotor akan memungkinkan bakteri $S$. aureus tumbuh banyak dan cepat. Pada saat sapi melakukan perebahan di lantai, maka ambing dan seluruh tubuh sapi akan kontak langsung dengan lantai, sehingga bakteri $S$. aureus yang berada di lantai akan menempel ke ambing dan dapat mencemari susu yang dihasilkan.

Selain mencemari susu, S. aureus juga dapat menginfeksi intramammae yang bersifat klinis maupun subklinis (Cahyono, 2013). Hal tersebut sesuai dengan pendapat Akineden (2001), yang menyatakan bahwa ambing yang terjangkit mastitis memiliki jumlah $S$. aureus yang sangat banyak. Penyebaran $S$. aureus pada ambing yang terinfeksi mastitis dapat terjadi selama proses pemerahan.

Kebersihan pemerah menjadi salah satu penyebab tingginya jumlah $S$. aureus. Menurut Suwito (2018), kurangnya pemahaman akan sanitasi seperti mencuci tangan dapat menyebabkan $S$. aureus mencemari susu. Peternakan sapi perah di Kecamatan Gisting dan Air Naningan melakukan pemerahan menggunakan mesin pemerah. Peternakan sapi perah di Kecamatan Air Naningan melakukan pemandian pada sapi perah dan pemerah hanya melakukan pengelapan pada ambing dengan air hangat, setelah itu ambing langsung diperah untuk mendapatkan susunya. Sedangkan pada peternakan sapi perah di Kecamatan Gisting, setelah sapi dimandikan, ambing dilap, namun pemerah tidak langsung melakukan pemerahan 
dengan mesin. Pemerah melakukan pemerahan 1-2 pemerahan untuk membuang susu diawal pemerahan, dari sapi satu ke sapi lainnya sampai selesai tanpa melakukan sanitasi pada tangan. Setelah itu dilanjut dengan proses pemerahan dengan mesin oleh pemerah yang berbeda. Menurut Suwito (2014), ternak perah yang diperah oleh orang yang berganti-ganti menyebabkan stres dan trauma pada ambing ternak, sehingga susu yang dihasilkan tidak lancar dan dapat menyebabkan mastitis.

Tabel 2. Jumlah Staphylococcus aureus pada susu sapi perah di Kabupaten Tanggamus

\begin{tabular}{ccc} 
No & Kode Sampel & Staphylococcus aureus $(\mathrm{CFU} / \mathrm{ml})$ \\
\hline 1 & $\mathrm{G} 1$ & $0^{*}$ \\
2 & $\mathrm{G} 2$ & $0^{*}$ \\
3 & $\mathrm{G} 3$ & $0^{*}$ \\
4 & $\mathrm{G} 4$ & $0^{*}$ \\
5 & $\mathrm{G} 5$ & $0^{*}$ \\
6 & $\mathrm{G} 6$ & $3,0 \times 10^{1 *}$ \\
7 & $\mathrm{G} 7$ & $0^{*}$ \\
8 & $\mathrm{G} 8$ & $2,7 \times 10^{1 *}$ \\
9 & $\mathrm{G} 9$ & $0^{*}$ \\
\hline & Rata-rata & $0,63 \times 10^{1 *}$ \\
\hline 10 & $\mathrm{~A} 1$ & $0^{*}$ \\
11 & $\mathrm{~A} 2$ & $0^{*}$ \\
12 & $\mathrm{~A} 3$ & $0^{*}$ \\
13 & $\mathrm{~A} 4$ & $0^{*}$ \\
14 & $\mathrm{~A} 5$ & $0^{*}$ \\
15 & $\mathrm{~A} 6$ & $2,6 \times 10^{1 *}$ \\
16 & $\mathrm{~A} 7$ & $0^{*}$ \\
17 & $\mathrm{~A} 8$ & $0^{*}$ \\
18 & $\mathrm{~A} 9$ & $0^{*}$ \\
19 & $\mathrm{~A} 10$ & $0^{*}$ \\
\hline & Rata-rata & $0,26 \times 10^{1 *}$ \\
\hline
\end{tabular}

Keterangan :

$\mathrm{G}$ : Gisting;

A : Air Naningan;

(*) : Sesuai SNI $\left(<1 \times 10^{2} \mathrm{cfu} / \mathrm{ml}\right)$;

$(* *)$ : Tidak Sesuai SNI $\left(>1 \times 10^{2} \mathrm{cfu} / \mathrm{ml}\right)$

Menurut Oliveira et al. (2011), mastitis yang disebabkan oleh $S$. aureus dapat mengakibatkan demam, tekanan darah menurun, pembesaran organ ambing dan dapat mengakibatkan kematian pada ternak. Menurut Suwito (2018), tangan pemerah merupakan salah satu sumber $S$. aureus yang dapat mengkontaminasi susu. Staphylococcus aureus dapat ditemukan pada bagian permukaan kulit, mukosa mulut, hidung, dan kulit kepala (Suwito, 2010). Usaha untuk meminimalisir terjadinya kontaminasi bakteri dari luar dengan penggunaan sarung tangan yang bersih selama proses pemerahan dan lap yang sudah direndam dengan larutan desinfektan untuk pengelapan ambing sangat penting dilakukan (Plozza et al., 2011). Penggunaan peralatan yang kurang bersih juga dapat menyebabkan $S$. aureus mencemari susu.
Peralatan yang digunakan pada peternakan sapi perah di Kabupaten Tanggamus sudah dicuci dengan air bersih dan sabun, sehingga dapat meminimalisir bakteri yang nantinya dapat mencemari susu. Kebersihan air yang digunakan untuk membersihkan peralatan pemerahan dapat mempengaruhi kualitas susu. Selain itu, peralatan yang digunakan telah disimpan di tempat yang bersih. Menurut Rombaut (2005), tempat penyimpanan peralatan yang kurang bersih dapat memungkinkan terjadinya pertumbuhan $S$. aureus.

Perilaku sapi yang suka menjilati sapi yang lain juga dapat menyebabkan $S$. aureus menempel pada badan bahkan ambing sapi yang sedang laktasi, sehingga $S$. aureus dapat mengkontaminasi susu yang dihasilkan. Kontaminasi tersebut dapat menyebabkan foodborne disease bagi konsumen. Hal tersebut 
sesuai dengan pendapat Suwito dan Andriani (2012), bahwa $S$. aureus termasuk bakteri Gram positif dan banyak terdapat pada permukaan kulit, mukosa hidung, mulut dan rambut.

Susu sapi yang dihasilkan pada peternakan sapi perah di Kabupaten Tanggamus Provinsi Lampung memiliki nilai $S$. aureus di bawah batas maksimum dan memenuhi syarat akan susu segar yaitu $<1 \times 10^{2} \mathrm{cfu} / \mathrm{ml}$. Jumlah $S$. aureus yang rendah menunjukkan bahwa susu aman dan layak untuk dikonsumsi oleh masyarakat, terlebih jika susu diolah terlebih dahulu.

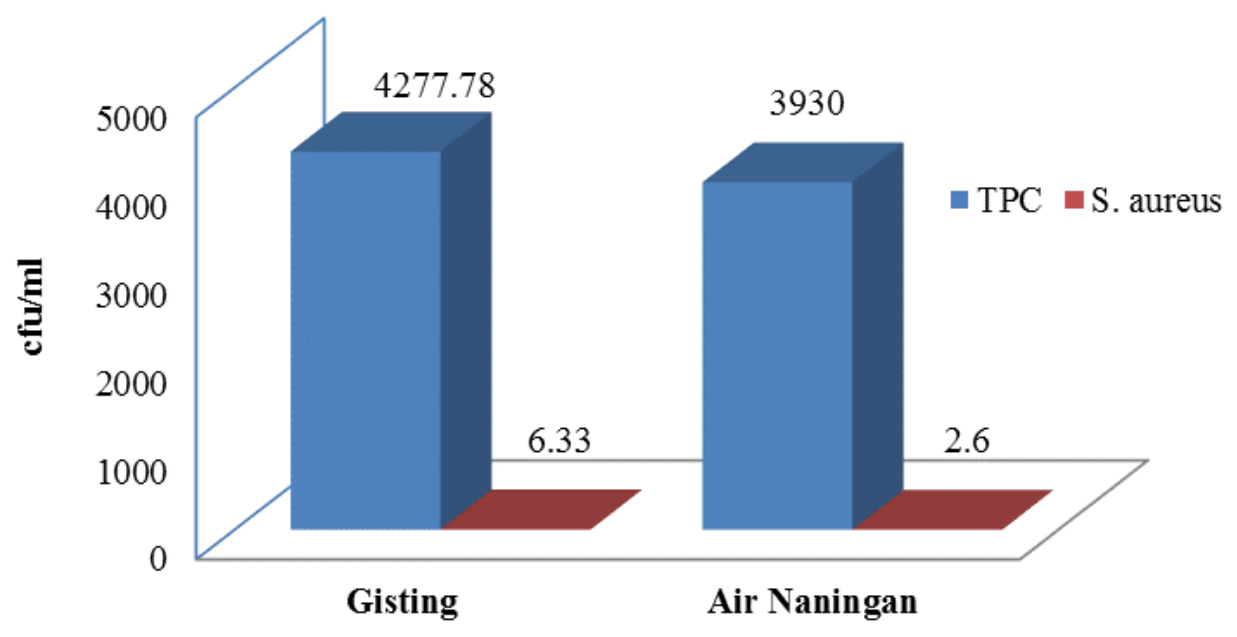

Gambar 1. Rata-rata Total Plate Count dan Staphylococcus aureus pada Susu Sapi Perah di Kabupaten Tanggamus

Jumlah $S$. aureus yang tinggi pada susu atau melebihi batas maksimum yaitu sebesar $1 \times 10^{2} \mathrm{cfu} / \mathrm{ml}$ akan menghasilkan toksin dan dapat menyebabkan keracunan bagi orang yang mengkonsumsi susu tersebut (Alarcon et al., 2006). Menurut Jorgensen et al. (2005), S. aureus merupakan salah satu bakteri penyebab keracunan setelah meminum susu yang tercemar. Jumlah $S$. aureus $>10^{4} \mathrm{cfu} / \mathrm{ml}$ pada susu akan menghasilkan toksin dalam susu dan apabila dikonsumsi akan menyebabkan mual, muntah, dan diare (Suwito, 2010).

\section{Hubungan Total Plate Count dan Staphylococcus aureus}

Hasil pada Tabel 1 menunjukkan bahwa sampel susu dengan kode $6 \mathrm{~A}, 3 \mathrm{~A}, 6 \mathrm{G}, 8 \mathrm{G}, 3 \mathrm{G}$, dan $4 \mathrm{G}$ merupakan sampel susu yang memiliki nilai TPC paling tinggi pada peternakan sapi perah di Kabupaten Tanggamus yaitu masingmasing sebesar $1,3 \times 10^{4} ; 1 \times 10^{4} ; 1,1 \times 10^{4} ; 9 \times 10^{3}$; $9 \times 10^{3}$; dan $9 \times 10^{3} \mathrm{cfu} / \mathrm{ml}$. Dari beberapa sampel susu yang memiliki nilai TPC tinggi tersebut hanya ada tiga sampel yang mengandung bakteri S. aureus (Tabel 2) yaitu pada sampel susu dengan kode $6 \mathrm{~A}, 6 \mathrm{G}$, dan $8 \mathrm{G}$ dengan masingmasing jumlah bakteri $S$. aureus sebesar $2,6 \times 10^{1}$; $3 \times 10^{1}$; dan $2,7 \times 10^{1} \mathrm{cfu} / \mathrm{ml}$.
Tabel 1 dan Tabel 2 menunjukkan bahwa tingginya nilai TPC pada susu, diiringi dengan tingginya jumlah $S$. aureus pada susu. Sampel susu yang memiliki nilai TPC cukup tinggi namun tidak terdapat adanya bakteri $S$. aureus di dalam susu, dapat terjadi karena adanya kontaminasi berbagai mikroba di luar tubuh sapi setelah proses pemerahan. Mikroba dapat mencemari susu melalui permukaan ambing, pemerah, alat-alat pemerahan, air, udara, dan tempat penyimpanan susu (Lund et al., 2000). Adanya ambing yang terjangkit mastitis dapat menyebabkan pencemaran $S$. aureus yang cukup tinggi di dalam susu yang dihasilkan, karena penyakit mastitis dapat disebabkan oleh adanya bakteri $S$. aureus yang masuk ke dalam ambing (Akineden, 2001).

Sanitasi yang benar pada pemerah akan menurunkan jumlah kontaminasi bakteri S. aureus dalam susu. Menurut Suwito (2018), pemerah susu termasuk faktor resiko terjadinya kontaminasi $S$. aureus di dalam susu, dengan mencuci tangan sebelum dan sesudah melakukan pemerahan akan menurunkan kontaminasi S. aureus. 


\section{SIMPULAN DAN SARAN}

\section{Simpulan}

1. Jumlah Total Plate Count (TPC) pada semua susu sapi perah di Kabupaten Tanggamus Provinsi Lampung berada di bawah batas maksimum $\left(1,0 \times 10^{6} \mathrm{cfu} / \mathrm{ml}\right)$ atau telah memenuhi syarat SNI tentang susu segar yaitu sebesar $1,0 \times 10^{1}-1,3 \times 10^{4} \mathrm{cfu} / \mathrm{ml}$;

2. Semua sampel susu sapi perah di Kabupaten Tanggamus Provinsi Lampung memiliki jumlah Staphylococcus aureus di bawah batas maksimum $\left(1,0 \times 10^{2} \mathrm{cfu} / \mathrm{ml}\right)$ atau telah memenuhi syarat SNI tentang susu segar, yaitu sebesar $0--3 \times 10^{1} \mathrm{cfu} / \mathrm{ml}$.

\section{Saran}

1. Peternak agar tetap memperhatikan manajemen pemerahan dan kebersihan saat pemerahan;

2. Peternak sebaiknya melakukan perbaikan tata letak perkandangan, khususnya tempat pembuangan limbah.

\section{DAFTAR PUSTAKA}

Akineden, O., C. Annemuller, A. Hasan, C. Lammler, W. Wolter, dan M. Zschok. 2001. Toxin Genes and Other Characteristics of Staphylococcus aureus Isolates from Milk of Cow with Mastitis. Clinical and Diagnostic Lab Immunol 8(5): 959-964.

Alarcon, B., B. Vicedo, dan R. Aznar. 2006. PCR Based Procedures for Detection and Quantification of Staphylococcus aureus and Their Application in Food. J. of Applied Microbiology. 100: 352-364.

Azwar, A. 1996. Pengantar Ilmu Kesehatan Lingkungan. Mutiara Sumber Widya. Jakarta.

Badan Standarisasi Nasional. 2011. SNI Nomor 3141.1:2011. Susu Segar-Bagian 1. Badan Standarisasi Nasional. Jakarta.

Berliana. 2016. Analisis Bakteri Udara sebagai Upaya Pemantauan dan Pencegahan Infeksi Nosokomial di Rumah Sakit. $J$. Husada Mahakam 4(3): 141-150.

Cahyono, D., C. H. Masdiana, Padaga, dan E. S. Manik. 2013. Kajian Kualitas Mikrobiologis (Total Plate Count (TPC), Enterobacteriaceae dan Staphylococcus Aureus) Susu Sapi Segar di Kecamatan Krucil Kabupaten Probolinggo. J. Ilmu dan Teknologi Hasil Ternak. 8(1): 1-8.

Darmansah, I. 2011. Penilaian Kualitas Susu Sapi Berdasarkan Jumlah Total
Mikroorganisme, Escherichia coli dan Staphylococcus aureus di Kabupaten Bogor, Cianjur, Bandung, Sumedang, dan Tasikmalaya, Provinsi Jawa Barat. Skripsi. Institut Pertanian Bogor. Bogor.

Direktorat Jenderal Peternakan dan Kesehatan Hewan. 2018. Statistik Peternakan dan Kesehatan Hewan. Kementerian Pertanian RI.

Elmoslemany, A. M., G. P. Keefe, I. R. Dohoo, J. J. Witchel, H. Stryhn, dan R.T. Dingwell. 2010. The Association between Bulk Tank Milk Analysis for Raw Milk Quality and On-Farm Management Practices. Preventive Veterinary Medicine. 95: 32-40.

Frank, J. F. 2001. Milk and Dairy Products. Dalam Doyle, M. P. Food Microbiology: Fundamentals and Frontiers. Edisi ke-2. Sam Press. Washington DC.

Hijriah, P. F., P. E. Santosa, dan V. Wanniatie. 2016. Status Mikrobiologi (Total Plate Count, Coliform, dan Escherichia coli) susu kambing Peranakan Etawa (PE) di Desa Sungai Langka Kecamatan Gedong Tataan Kabupaten Pesawaran. J. Ilmiah Peternakan Terpadu. 4(3): 217-221.

Jayani, D. H. 2019. Jumlah Penduduk Indonesia Tahun 2019. https://databoks.katadata.co.id/datapublis h/ 2019/04/29/ jumlah-pendudukindonesia-269-juta-jiwa-terbesarkeempat-dunia. Diakses pada 28 Oktober 2019.

Jorgensen, H.J., T. Mork, H.R. Hogasen, dan L.M. Rorvik. 2005. Enterotoxigenic Staphylococcus aureus in Bulk Milk in Norway. J. of Applied Microbiology 99: 158-166.

Lund, B. M., T. C. Baird-Parker, dan G. W. Gould. 2000. The Microbiological Safety and Quality of Food. Volume 1. Aspen Publisher. Maryland.

Oliveira, L., A. C. Rodrigues, C. Hulland, dan P. L. Ruegg. 2011. Enterotoxin Production, Enterotoxin Gene Distribution, and Genetic Diversity of Staphylococcus aureus Recovered from Milk of Cows with Subclinical Mastitis. J. of Veterinary Research. 72: 1361-1367.

Pemerintah Kabupaten Tanggamus. 2019. Sejarah Tanggamus http://www.tanggamus.go.id/index.php/ profil/sejarah. Diakses pada November 2019.

Permatasari, R. I. 2018. Higiene, Sanitasi dan Kualitas Bakteriologis Susu Sapi di Dusun Krajan, Desa Gendro, Kecamatan 
Tutur Kabupaten Pasuruan. J. Kesehatan Lingkungan. 10(4): 343-350.

Plozza K., G. G. Lievaart, G. Potts, dan H. W. Barkema. 2011. Subclinical Mastitis and Associated Risk Factors on Dairy Farms in New South Wales. Australian Veterinary J.. 89: 41-46.

Rombaut, R. 2005. Dairy Microbiology and Starter Cultures. Laboratory of Food and Engineering. Gent University. Belgium.

Santoso, I., S. Wijana, dan W. H. Pratiwi. 2010. Penerapan Logika Fuzzy pada Penilaian Mutu Susu Segar. J. Teknologi Pertanian. 11(1): 47-53.

Santoso, L., M. G. I. Rukmi, dan O. Lestari. 2012. Jumlah Total Bakteri dan Coliform dalam Air Susu Sapi Segar pada Pedagang Pengecer di Kota Semarang. $J$. Kesehatan Masyarakat. 1(2): 402-412.

Suwito, W. 2010. Bakteri yang sering Mencemari Susu: Deteksi, Patogenesis, Epidemiology, dan Cara Pengendaliannya. J. Litbang Pertanian. 29(3): 96-100.

Suwito, W. dan Andriani. 2012. Teknologi Penanganan Susu yang Baik dengan Mencermati Profil Mikroba Susu Sapi di Berbagai Daerah. J. Pascapanen. 9(1): $35-44$.

Suwito, W., W. S. Nugroho, A. E. T. H Wahyuni, dan B. Sumiarto. 2014. Analisis Mikrobiologi Susu Kambing Peranakan Ettawa (PE) dari Kabupaten Sleman Yogyakarta. J. Kesehatan Hewan. 8(2): 101-104.

Suwito W., E. Winarti, F. Kristiyanti, A. Widyastuti, dan A. Andriani. 2018. Faktor Risiko terhadap Total Bakteri, Staphylococcus aureus, Koliform, dan Escherichia coli pada Susu Kambing. Agritech. 38(1): 39-44.

Syamsi, A. N., T. Y. Astuti, dan H. S. Widodo. 2018. Kajian Keamanan Pangan dan Tingkat Prevalensi Cemaran Bakteri Susu di Sentra Pengembangan Sapi Perah Cilongok. J. Ilmu-ilmu Peternakan. 28(3): 224-232.

Syarif, E. Kemal, dan B. Harianto. 2011. Buku Pintar Beternak dan Bisnis Sapi Perah. Agromedia Pustaka. Jakarta.

Wanniatie, V., M. B. Sudarwanto, T. Purnawarman, dan A. Jayanegara. 2019. Comparison of Microbiological Quality between Organic and Conventional Goat Milk: a Study Case in Bogor, Indonesia. Advances in Animal and Veterinary Sciences. 7(7): 593-598

Wiryono. 2013. Pengantar Ilmu Lingkungan. Pertelon Media. Bengkulu. 